
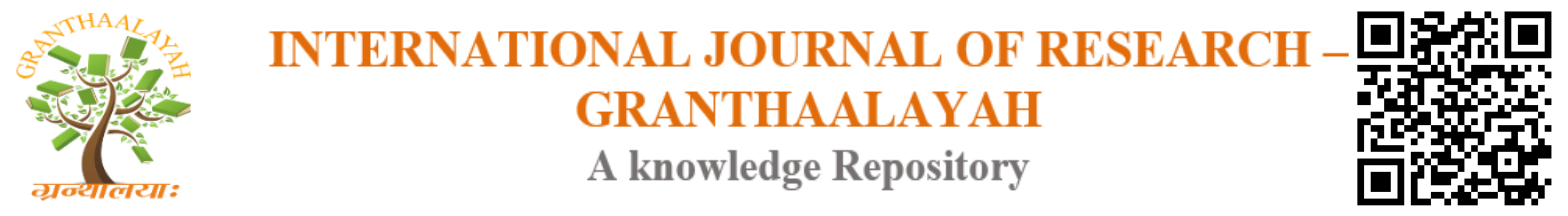

Science

\title{
CASE STUDY - MANAGEMENT OF AVABAHUKA WITH SPECIAL REFERENCE TO FROZEN SHOULDER BY AYURVEDIC MEDICINE
}

\author{
Dr. Aditya Sanjaykumar Dalvi ${ }^{1}$, Dr. Akshay Santosh Gandhi ${ }^{2}$ \\ ${ }^{1,2}$ UG Student, SGR Ayurved Collage Solapur, Maharashtra, India
}

\begin{abstract}
Avabahuka is a disease that usually affects the Ansasandhi (shoulder joint). In the sedentary and restless lifestyle of people both aharaj and viharaj hetu and least importance to physical exercises affects the body and produce disease

Avabahuka was first introduced by Susruta where pain and stiffness of shoulder joint leads to severely restricted movement of hand. As the disease is purely caused by affliction of vayu and the symptoms come due to aggravation of vayu so vatanashaka therapy may be advocated as remedy of the same. Self reported prevalence of shoulder pain is estimated to be between $16 \%$ and $26 \%$.

Here I present the case of 48 years old Female patient, whose early diagnosis of Frozen Shoulder permitted successful management according to ayurvedic principles. Though initially severe pain and stiffness, than she return to normal life after treatment.
\end{abstract}

Keywords: Reference; Frozen; Shoulder; Ayurvedic Medicine.

Cite This Article: Dr. Aditya Sanjaykumar Dalvi, and Dr. Akshay Santosh Gandhi. (2019). "CASE STUDY- MANAGEMENT OF AVABAHUKA WITH SPECIAL REFERENCE TO FROZEN SHOULDER BY AYURVEDIC MEDICINE." International Journal of Research - Granthaalayah, 7(3), 116-119. https://doi.org/10.29121/granthaalayah.v7.i3.2019.950.

\section{Introduction}

Frozen Shoulder is also known as Adhesive Causalities. It is a painful and disabling disorder of shoulder capsule. Frozen shoulder most commonly affect the people between the age of 40 to 60 and occurs in women more often than man. The connective tissue surrounding the glenohumeral joint of shoulder becomes inflamed and stiff, greatly restricting movement and causing chronic pain. Pain is usually constant, worse at night and with cold weather. Certain movement can provoke tremendous pain and cramping. Risk factors for frozen shoulder include tonic seizures, DM, stroke, accidents, lung disease, connective tissue disorder and heart disease. The terms frozen shoulder describes the symptoms like movement of the shoulder is severely restricted, with progressive loss of both active and passive range of motion. In frozen shoulder, there is a lack of synovial fluid, which normally helps the shoulder joint. The shoulder capsule thickens, swells and tightens due to band of scar tissue. In Ayurveda, Frozen Shoulder is compare with Avbahuka 
disease. Avbahuka is a Vatavyadhi. It is a desease that usually affect the AnsaSandhi (shoulder joint). Ansa Shosha can be considered as the preliminary stage, where loss or dryness of Shleshaka kapha from ansasandhi occurs. The next stage, that is, avabahuka occurs due to the loss of shleshska kapha and symptoms like Ansashoola (shoulder pain) during movement, restricted movement and so on are manifested.

A48 years old Female patient, presenting with Pain and stiffness in Left shoulder, Restricted movement, Tightness in left shoulder since 4 month diagnosed as Avabahuka was brought to SSNJ Ayurved Hospital, Solapur. Patient was treated with an integrated approach of ayurveda. According to ayurveda, treatment given for this vyaadhi is Vatanashaka and Pain and stiffness reliever, Snehan Jambirpottalli Swedan, Avapidak Snehapana, Agnikarma And Nasya. Proper diet and Poor exercise is given. Appreciable results were observed in the form of reduction of Symptoms.

\section{Case}

PATIENT NAME- XYZ

AGE- 48 yrs. SEX- Female

Occupation- Housewife

Reg. No.19783/209

D.O.A-05/10/2018

D.O.D-15/10/2018

$\mathrm{C} / \mathrm{O}$-Pain and stiffness in Left shoulder

-Restricted movement

-Tightness in right shoulder -since 4 month.

No H/O- Malaria/Typhoid/Jaundice.

No K/C/O- HTN/DM/PTB/BA/Epilepsy.

No H/O- Any Surgical illness.

No H/O- Any Drug Allergy.

O/E- GC- Fair \& A febrile

$\mathrm{P}-84 / \mathrm{min}$

BP-120/90 mm of hg

S/E- RS- AEBE Clear

CVS-S1 \& S2 Normal

P/A - soft \& non-tender

Urine-passed

Stool-Passed

Deep Tendon Reflex-

\begin{tabular}{|l|l|l|l|l|}
\hline & Knee Jerk & Ankle Jerk & Biceps Jerk & Triceps Jerk \\
\hline Right & $2+$ & $2+$ & $2+$ & $2+$ \\
\hline Left & $2+$ & $2+$ & $2+$ & $2+$ \\
\hline
\end{tabular}

Muscle Power Grade
\begin{tabular}{|l|c|c|}
\hline MPG & RT & LT \\
\hline UP & $5 / 5$ & $5 / 5$ \\
\hline LP & $5 / 5$ & $5 / 5$ \\
\hline
\end{tabular}




\section{Investigations}

$\mathrm{Hb}-11 \%$;

RBC-4300;

WBC-6000;

ESR-13;

Platelets- 225000

RA, VDRL, HbsAg -Negative

$\mathrm{X}$-ray of B/L shoulder- Normal.

\section{NIDANPANCHAKA}

\section{Hetu-}

Bahya hetu - Causing injury to left shoulder.

Abhyantar hetu- Vatana, Udid, Gahu, Mash etc. Sevan

\section{Samprapti}

\section{HETU SEVANA}<smiles>C1CCC1</smiles>

VAATPRAKOPA<smiles>C1CCC1</smiles>

Loss or Dryness of Shleshaka kapha and shushkata increases<smiles>C1CCC1</smiles>

Pain and stiffness in left shoulder, restricted movement<smiles>C1CCCC1</smiles>

\section{Avabahuka (Frozen Shoulder)}

Poorvaroopa- Mild pain and stiffness

Roopas -Moderate Pain and stiffness in Left shoulder, restricted movement Since 4 Months

\section{Treatment Given}

\section{Panchakarma}

- Sthanik Snehan with Mahanarayana Tail \& Jambir Pottali Swedan x 10 days

- Nasya with panchendriya Vardhana Tail x 10 days

- Agni Karma on Rt. Shoulder region x 3 times

- Avapidaka Sneh with Goghrita $10 \mathrm{ml}$ Before \& After meal. 


\section{Oral}

- Tab. Yograj Guggulu (500mg) TDS x 10 days

- Maharasnadi Kwath 20 ml BD x 10 days

- Trivruttavleha 10 gm with Koshna Jal at night.

\section{After Treatment}

No pain and stiffness of left shoulder, freely movement of the joint.

ON DISCHARGE- Patient is advised oral medicines and regular follow up in OPD.

\section{Discussion}

Initially when patient came to us, patient was suffering from the disease almost since 4 month. Having pain and stiffness in left shoulder, Restricted movement and tightness in the shoulder. After therapy of ten days, patients relief from above complains. There is no other complains. Patient can now do his routine work without taking NSAIDS.

We have manage this patient with the help of Ayurvedic Medicines \& Panchakarma.

\section{Conclusion}

The case highlight the fact that confidence can be placed in Ayurvedic treatment principles even in a case where modern medicines progress is poor. The patient was diagnosed in Ayurvedic term and treated accordingly Sthanik Snehan \& Jambir pottali Swedan, Agni Karma, Nasya \& Avapidak Sneha in case of frozen shoulder. Patient can now do his routine work without taking NSAIDS.

\section{References}

[1] Madhav Nidan/Vata vyadhi/64.

\footnotetext{
*Corresponding author.

E-mail address: dalviaditya1998@gmail.com/ akshay26gandhi@gmail.com
} 